\title{
Nutritional balance and yield for green manure orange trees
}

\section{Balanço nutricional e produtividade em laranjeiras manejadas com adubação verde}

\author{
Carlos Renato Alves Ragozo ${ }^{\mathrm{I}}$ Sarita Leonel ${ }^{\mathrm{I}}{ }^{*}$ Marco Antonio Tecchio ${ }^{\mathrm{II}}$
}

\section{ABSTRACT}

Intercropping could efficiently prevent soil nutrient losses caused by extensive agriculture. The present study aimed to assess the effect of green manure on the nutritional status of orange trees cultivar 'Pera'(Citrus sinensis (L.) Osbeck). The plants were grafted on 'Cravo'lime trees and were then planted in a $7 \times 4 m$ space. Four different treatments corresponding to the evaluated green manures were employed: jack bean (JB) (Canavalia ensiformis $D C$ ), lablab (LL) (Dolichos lablab L.), pigeon pea (PP) (Cajanus cajan L. Millsp), and Brachiaria (BQ) (Brachiaria brizantha Hochst ex A. Rich. Stapf) as control. The experimental design was in randomized blocks, in split-plot time, with six replicates, with four treatments (green manures) and two plants per evaluation. The nutritional status was assessed by using the DRIS method (Diagnosis and Recommendation Integrated System); the yield and the macro and micronutrient levels contained in green manures and in the control was also determined. The nutritional diagnosis indicated that, in the two years of experiment, plants treated with green manure showed better nutritional balance index compared to Brachiaria. This suggests that, over time, green manure can lead to better nutritional balance. Pigeon pea treatment showed the highest yields, compared to control, in the two evaluated crop cycles (2004/05 and 2005/06).

Key words: Citrus sinensis, Citrus limonia, intercropping, diagnosis and recommendation integrated system.

\section{RESUMO}

O manejo de culturas intercalares poderia prevenir eficientemente as perdas de nutrientes do solo, causadas pelo cultivo extensivo. $O$ trabalho teve como objetivo avaliar o efeito da utilização de adubos verdes no estado nutricional de plantas de laranjeira 'Pêra' (Citrus sinensis (L.) Osbeck). O solo da área de cultivo é denominado Neossolo Quartzarênico. As plantas estavam enxertadas em limoeiro 'Cravo' e foram plantadas num espaçamento de sete por quatro metros. Foram empregados quatro tratamentos correspondentes aos adubos verdes avaliados, sendo eles: feijão de porco (FP) (Canavalia ensiformis DC), labe-labe (LL) (Dolichus lablab L.), feijão guandu anão (GA) (Cajanus cajan L. Millsp) e braquiária (BQ) (Brachiaria brizantha Hochst ex A. Rich. Stapf). Conduziuse o experimento em delineamento de blocos casualizados em esquema de parcelas subdivididas no tempo, com seis repetições, quatro tratamentos (adubos verdes) e duas plantas úteis para as avaliações. Avaliou-se o estado nutricional pelo método DRIS (Sistema Integrado de Diagnose e Recomendação), bem como a produção e o teor de macro e micronutrientes contidos nos adubos verdes e na testemunha. O diagnóstico nutricional demonstrou que, nos dois anos de experimentação, houve um melhor índice de balanço nutricional para os adubos verdes, quando comparados com a braquiária (testemunha). Esta constatação permite inferir sobre a disponibilidade de, ao longo do tempo, os adubos verdes permitirem um melhor equilíbrio nutricional para as plantas. $O$ tratamento com feijão de porco apresentou as maiores produções, quando comparado com a testemunha, nos dois ciclos agrícolas de avaliação (2004/05 e 2005/06).

Palavras-chave: Citrus sinensis, Citrus limonia, culturas intercalares, sistema integrado de diagnose e recomendação.

\section{INTRODUCTION}

Citriculture in São Paulo State, Brazil, is concentrated in regions of low fertility soils, as stated by DEMATTÊ \& VITTI (1992), who detected medium-textured soils (clay content of 15\%-35\% at the soil surface) for $65 \%$ of the evaluated areas; sandy soils (clay content of up to 15\%) for $30 \%$, and clayish

IConsultor em citros, Botucatu, SP, Brasil.

IDepartamento de Horticultura, Faculdade de Ciências Agronômicas (FCA), Universidade Estadual Paulista (UNESP), Rua José Barbosa de Barros, 1780, 18610-307, Botucatu. SP. Brasil. E-mail: sarinel@fca.unesp.br. *Autor para correspondência. 
soils for approximately 5\%. This has forced the producer to use external inputs to make the activity viable, increasing thus citrus production costs.

In the last few years, consumers, especially from the external market, have become increasingly interested in food security, particularly in production means. This has motivated the search for alternatives of low environmental impact, including the use of cover or green manure crops (SAN MARTIN MATHEIS, 2008).

Green fertilization consists in incorporating into the soil a non-decomposed mass of plants locally cultivated or imported in order to preserve and/or recover the productivity of cultivable lands. According to scientific studies and practical evidence, green manure acts on diverse soil fertility aspects by: increasing dry matter content; decreasing $\mathrm{Al}$ and $\mathrm{Mn}$ toxicity due to the high complexity and $\mathrm{pH}$; promoting nutrient recycling; extracting and mobilizing nutrients from the deepest layers of the soil and subsoil, including $\mathrm{Ca}, \mathrm{Mg}, \mathrm{K}, \mathrm{P}$ and micronutrients; extracting fixed phosphorus; and fixing atmospheric $\mathrm{N}$ symbiotically with Leguminosae (VON OSTERROHT, 2002).

Reasonable intercropping could lead crops and trees to completely use light, heat, water and nutrient resources, efficiently preventing water and soil losses and fertility reduction. The main interspecific relationships are facilitation and competition, which occur together in the intercropping system. When competition is higher than facilitation, intercropping is significant disadvantageous, whereas when competition is lower than facilitation, intercropping is considerably advantageous (ZHOU et al., 2009).

The current study aimed to evaluate, based on DRIS and on macro and micronutrient levels of green manure and control treatments, the nutritional balance and the yield of an orchard of orange trees 'Pêra' with the introduction of green manure.

\section{MATERIAL AND METHODS}

The present experiment was carried out at the farm "Três Irmãos”, Botucatu, São Paulo State, Brazil, located at 2252'25.0”S and 48³7'50.3”W; $844 \mathrm{~m}$ altitude. The climate in this region is classified as of Cwa type (MELLO et al., 1994). Annual average precipitation is $1445 \mathrm{~mm}$, annual average temperature, $21.0^{\circ} \mathrm{C}$, and evapotranspiration, $700 \mathrm{~mm}$. The soil at the farm is sandy and excessively drained, containing small percentage of exchangeable bases and low saturation; which it is called Oxic Quartzipsamments (EMBRAPA, 1999).

According to the soil analyses carried out before the treatments, the crop lines had the following features: At 0-20 cm depth, $\mathrm{pH}\left(\mathrm{CaCl}_{2}\right)$ 7.4; Organic Matter $12 \mathrm{~g} \mathrm{dm}^{-3}$; P $18 \mathrm{mg} \mathrm{dm}^{-3}$; $\mathrm{H}+\mathrm{Al} 14 \mathrm{mmol}_{\mathrm{c}} \mathrm{dm}^{-3}$; $\mathrm{K} 0.4 \mathrm{mmol}_{\mathrm{c}} \mathrm{dm}^{-3}$; Ca $40 \mathrm{mmol}_{\mathrm{c}} \mathrm{dm}^{-3}$; $\mathrm{Mg} 32 \mathrm{mmol}$ $\mathrm{dm}^{-3}$; Sum of bases $72 \mathrm{mmol}_{\mathrm{c}} \mathrm{dm}^{-3}$; Cation exchange capacity CEC $86 \mathrm{mmol}_{\mathrm{c}} \mathrm{dm}^{-3}$; Base saturation (V\%) 84; B $0.20 \mathrm{mg} \mathrm{dm}^{-3}$; Cu $0.7 \mathrm{mg} \mathrm{dm}^{-3}$; Fe $20 \mathrm{mg} \mathrm{dm}^{-3}$; Mn $1.3 \mathrm{mg} \mathrm{dm}^{-3}$; Zn $0.8 \mathrm{mg} \mathrm{dm}^{-3}$. At $40 \mathrm{~cm}$ depth, $\mathrm{pH}$ $\left(\mathrm{CaCl}_{2}\right)$ 5.0; Organic Matter $11 \mathrm{~g} \mathrm{dm}^{-3} ; \mathrm{P} 6 \mathrm{mg} \mathrm{dm}^{-3} ; \mathrm{H}$

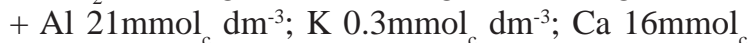
$\mathrm{dm}^{-3}$; $\mathrm{Mg} 8 \mathrm{mmol}_{\mathrm{c}} \mathrm{dm}^{-3}$; Sum of bases $25 \mathrm{mmol}_{\mathrm{c}} \mathrm{dm}^{-3}$; Cation exchange capacity CEC $46 \mathrm{mmol}_{\mathrm{c}} \mathrm{dm}^{-3}$; Base saturation (V\%) 54; B 0.13mg dm ${ }^{-3}$; Cu $0.6 \mathrm{mg} \mathrm{dm}^{-3}$; Fe 31mg dm ${ }^{-3}$; Mn 1.3mg dm ${ }^{-3}$; Zn $0.8 \mathrm{mg} \mathrm{dm}^{-3}$.

Soil analyses carried out in the intercropping before the treatments revealed the following features: at $0-20 \mathrm{~cm}$ depth, $\mathrm{pH}\left(\mathrm{CaCl}_{2}\right) 6.4$; Organic Matter 13g dm${ }^{-3}$; P 2mg dm${ }^{-3} ; \mathrm{H}+\mathrm{Al} 16 \mathrm{mmol}_{c}$

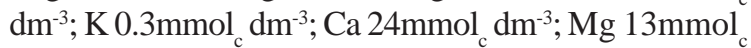
$\mathrm{dm}^{-3}$; Sum of bases $37 \mathrm{mmol} \mathrm{dm}^{-3}$; Cation exchange capacity CEC $53 \mathrm{mmol} \mathrm{dm}^{-3}$; Base saturation (V\%) 71; B $0.09 \mathrm{mg} \mathrm{dm}^{-3}$; Cu 0.3mg dm${ }^{-3}$; Fe $19 \mathrm{mg} \mathrm{dm}^{-3}$; Mn 0.8mg dm ${ }^{-3}$; Zn $0.2 \mathrm{mg} \mathrm{dm}^{-3}$. At $40 \mathrm{~cm}$ depth, $\mathrm{pH}$ $\left(\mathrm{CaCl}_{2}\right)$ 5.1; Organic Matter $8 \mathrm{~g} \mathrm{dm}^{-3} ; \mathrm{P} 1 \mathrm{mg} \mathrm{dm}{ }^{-3} ; \mathrm{H}$ $+\mathrm{Al} 16 \mathrm{mmol}_{\mathrm{c}} \mathrm{dm}^{-3}$; K $0.2 \mathrm{mmol}_{\mathrm{c}} \mathrm{dm}^{-3}$; Ca $14 \mathrm{mmol}_{\mathrm{c}}$

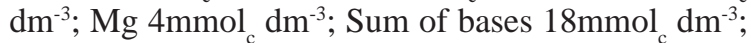
Cation exchange capacity CEC $34 \mathrm{mmol}_{\mathrm{c}} \mathrm{dm}^{-{ }^{-3}}$; Base saturation (V\%) 53; B 0.09mg dm${ }^{-3}$; Cu 0.3mg dm $\mathrm{m}^{-3}$; Fe 24mg dm ${ }^{-3}$; Mn 0.6mg dm $\mathrm{m}^{-3}$; $\mathrm{Zn} 0.1 \mathrm{mg} \mathrm{dm}^{-3}$.

The crown cultivar was the orange tree 'Pêra' (Citrus sinensis, Osbeck) grafted on 'Rangpur' lime (Citrus limonia, Osbeck). The commercial orchard was spaced $7 \mathrm{~m}$ apart between rows and $4 \mathrm{~m}$ apart between plants and was established in October 1996.

The adopted green manure was jack bean (Canavalia ensiformis DC), lablab (Dolichos lablab L.), pigeon pea (Cajanus cajan L. Millsp), and Brachiaria (Brachiaria brizantha Hochst ex A. Rich. Stapf) and cultivar Piatã as control. At fifteen days after Brachiaria mowing, 3L ha ${ }^{-1}$ glyphosate (Roundup) was applied onto the areas previously planted with green manure. In December 2004 ( $1^{\text {st }}$ year$)$ and December 2005 ( $2^{\text {nd }}$ year $)$, such soil-protector crops were directly planted. During planting, both green manure and control treatments received $40 \mathrm{~kg} \mathrm{ha}^{-1} \mathrm{P}_{2} \mathrm{O}_{5}$ as simple superphosphate.

Green manure treatments - Treatment 1: Jack Bean (JB); Treatment 2: Pigeon Pea (PP); and Treatment 3: Lablab (LL) - were sown on six 
rows spaced $50 \mathrm{~cm}$ apart from the orange tree crown projection. The number of seeds per linear meter for JB, PP and LL was 3, 20 and 10, respectively, which corresponds to approximately 80, 25 and $50 \mathrm{~kg}$ seeds per ha, proportionally to the viable area.

Harvest occurred during full flowering and beginning of legume formation, at approximately 120 days after sowing. The obtained biomass from both Leguminosae and Brachiaria was rubbed and sent to the plant rows. Experimental design was in randomized blocks, in split-plot in time, with six replicates, four treatments and two plants per evaluation totaling 24 plots, from which two plants were used for the tests while the others remained as border treatments (ROSSETTI, 2002). The plots were represented by four green manure treatments and the split plots by the two evaluated crop cycles (years). Each plot was composed of four plant rows spaced $7 \mathrm{~m}$ apart and each row had four plants spaced $4 \mathrm{~m}$ apart, occupying $252 \mathrm{~m}^{2}$. Analyses of variance were performed and when there was significance Tukey's test $(\mathrm{P}<0.05)$ was employed.

Samples of three and four leaves were collected at the beginning of fruiting (25 leaves per sampling), in spring sprouting. The samples were prepared and analyzed according to MALAVOLTA et al. (1998). A chemical analysis of the plants was carried out before the establishment of the experiment (Table 1). Nutrient content was also chemically analyzed according to MALAVOLTA et al. (1998). Results of leaf chemical analysis were subjected to DRIS (BEAUFILLS, 1973), a system that is based on the relationships among nutrients and that has as work unity parameters known as nutritional indexes which are determined by mathematical equations based on prefixed patterns, which in turn are used for a new leaf analysis. The nutritional balance index (NBI) is obtained based on the sum of the absolute values of all nutritional indexes for each treatment. Thus, in the present study, interpretation of leaf results for the different adopted treatments was carried out by using the DRIS method as per the norms developed by CRESTE \& NAKAGAWA (1997) for the lemon; since the experiment was located in the same farm, it was adopted as reference to compare. The yield was determined according to the total weight of fruits per plant and was expressed as kg.

\section{RESULTS AND DISCUSSION}

In general, $\mathrm{N}$ and $\mathrm{P}$ levels met the demands of plants and did not present any significant variation among treatments; however, there was slightly higher relative deficiency in the second year, compared to the first year of evaluation. K was one of the most limiting nutrients; it was observed in all deficient treatments and did not meet the demands of plants. Such deficiency probably resulted from the use of a formula with N/K ratio of $2 / 1$. From a nutritional point of view, calcium levels were close to equilibrium, but in slight relative excess, for all treatments (Tables 2 and 3).

All treatments showed relative $\mathrm{Mg}$ excess, which was compatible with the interpretation of QUAGGIO et al. (1996) and corroborated the reports of VITTI et al. (1996), suggesting soil Ca/Mg ratio of 4/1 for citrus plants. Treatments also showed relative $\mathrm{S}$ excess, which can be explained by the intense utilization of S-based acaricides.

Two interesting extremes were observed for the nutrient $B$. In the first year, its relative deficiency was rather clear. In the second year, however, there was a relative excess, although B was not applied via the soil. This can be explained by the effect of green manure on micronutrient extraction and mobilization at deeper soil and subsoil layers, as stated by VON OSTERROHT (2002). All treatments tended to show relative $\mathrm{Cu}$ excess in the first year, which in the second year changed to slight relative deficiency.

Fe levels were close to adequate. As already discussed, there was intense Mg deficiency in the first year, which was assuaged afterwards maybe by the efficient leaf fertilization employed. Zn was another main element diagnosed as deficient, indicating the need of specific and immediate actions, including increased levels, different formulations and larger number of applications.

Based on the lowest nutritional index values obtained by DRIS, treatments that showed the best nutritional relationship were PP, JB, LL,

Table 1 - Results of leaf chemical analysis before treatments. 2005 and 2006.

\begin{tabular}{|c|c|c|c|c|c|c|c|c|c|c|}
\hline $\mathrm{N}$ & $\mathrm{P}$ & K & $\mathrm{Ca}$ & $\mathrm{Mg}$ & $S$ & B & $\mathrm{Cu}$ & $\mathrm{Fe}$ & $\mathrm{Mn}$ & $\mathrm{Zn}$ \\
\hline \multicolumn{11}{|c|}{$\mathrm{kg}$} \\
\hline 26 & 1.5 & 11 & 42 & 4.9 & 3.6 & 56 & 103 & 136 & 9 & 25 \\
\hline
\end{tabular}


Table 2 - Leaf diagnosis using diagnosis and recommendation integrated system (DRIS) in the first experimental year (2005). FCA/UNESP/Botucatu. 2005 and 2006.

\begin{tabular}{lccccccccccccc}
\hline Treatment & $\mathrm{I}_{\mathrm{N}}$ & $\mathrm{I}_{\mathrm{P}}$ & $\mathrm{I}_{\mathrm{K}}$ & $\mathrm{I}_{\mathrm{Ca}}$ & $\mathrm{I}_{\mathrm{Mg}}$ & $\mathrm{I}_{\mathrm{S}}$ & $\mathrm{I}_{\mathrm{B}}$ & $\mathrm{I}_{\mathrm{Cu}}$ & $\mathrm{I}_{\mathrm{Fe}}$ & $\mathrm{I}_{\mathrm{Mn}}$ & $\mathrm{I}_{\mathrm{Zn}}$ & $\mathrm{I}_{\mathrm{MS}}$ & $\mathrm{NBI}$ \\
\hline Jack Bean & 0.1 & 0.1 & -1.5 & 0.6 & 0.8 & 1.2 & -0.2 & 0.6 & 0.1 & -0.7 & -0.9 & 0.7 & $7.5 \mathrm{~A}$ \\
Pigeon Pea & 0.1 & -0.2 & -0.4 & 0.7 & 0.9 & 1.3 & -0.3 & 0.8 & 0.3 & -0.9 & -1.0 & 0.6 & $8.5 \mathrm{~A}$ \\
Lablab & 0.1 & -0.3 & -1.1 & 0.7 & 0.7 & 1.3 & -0.4 & 0.6 & 0.1 & -1.0 & -1.2 & 0.5 & $9.0 \mathrm{~A}$ \\
Brachiaria & 0.1 & -0.2 & -2.9 & 0.7 & 2.7 & 1.3 & -0.4 & 0.6 & 0.1 & -0.7 & -1.0 & 0.6 & $11.3 \mathrm{~B}$ \\
DMS & & & & & & & & & & & & \\
CV (\%) & & & & & & & & & & & & & \\
\end{tabular}

NBI = Nutritional Balance Index.

Means followed by the same letter in the column are not statistically different according to Tukey's test at 5\% significance.

in the two years (Tables 2 and 3). This indicates that Leguminosae can provide a more appropriate nutritional relationship. The lower the NBI, the better the nutritional status, according to CRESTE (2008).

There was not significant interaction between the crop cycles (years) and the treatments (green manure). The mean levels of leaf nutrients in both crop cycles are shown in table 4. Green manure treatments presented higher levels of nutrients $\mathrm{N}$, Ca, B, Fe and Zn, compared to BQ treatment (Table 4), corroborating the results of WEBER \& PASSOS (1991), who reported that the nutrient levels of Brachiaria, among other natural Gramineae of citrus orchard, are lower than those of Leguminosae.

SILVA et al. (2002) evaluated green manure production and nutrients incorporated into the soil by intercropping Crotalaria juncea, Crotalaria spectabilis, Cajanus cajan, Mucuna aterrima, Mucuna deeringiana, Dolichos labe-labe and Canavalia ensiformis in an orchard of 'Pera' (Citrus sinensis L. Osbeck), grafted on Cleópatra mandarin (Citrus reshi Hort.). The average crop dry matter for the cultivated species in the four years of study was: 6.55, 1.23, 3.42, 1.78, 1.75, 1.61 and 3.03t $\mathrm{ha}^{-1}$, respectively. Chemical analysis of the material revealed considerable incorporation of $\mathrm{N}, \mathrm{P}_{2} \mathrm{O}_{5}, \mathrm{~K}_{2} \mathrm{O}$, $\mathrm{Ca}, \mathrm{Mg}, \mathrm{S}, \mathrm{B}, \mathrm{Fe}, \mathrm{Mn}$ and $\mathrm{Zn}$ by leguminous plants. C. juncea had the highest biomass production and nutrient incorporation, followed by $\boldsymbol{C}$. cajan and $\boldsymbol{C}$. ensiformis.

There was significant interaction between the crop cycles and the green manure treatments for the yield (Table 5). Pigeon pea enhanced the yield in both crop cycles when compared to the other treatments. Increased productivity using these green manure treatments (Table 5) resulted from the decomposition of such organic matter, which is richer in nutrients than the control (BQ), since all plant material was rubbed and sent to the orange tree rows. Pigeon pea enhanced the yield by 34.4\% (2005 crop cycle) and $47.4 \%$ (2006 crop cycle), compared to control (Brachiaria brizantha).

\section{CONCLUSION}

Plants treated with green manure showed better nutritional balance index than plants treated with Brachiaria brizantha Hochst ex A. Rich. Stapf. Pigeon pea is indicated as green manure to be used between rows of orange trees 'Pêra'.

Table 3 - Leaf diagnosis using diagnosis and recommendation integrated system (DRIS) in the second experimental year (2006). FCA/UNESP/Botucatu. 2005 and 2006.

\begin{tabular}{|c|c|c|c|c|c|c|c|c|c|c|c|c|c|}
\hline Treatment & $\mathrm{I}_{\mathrm{N}}$ & $\mathrm{I}_{\mathrm{P}}$ & $\mathrm{I}_{\mathrm{K}}$ & $\mathrm{I}_{\mathrm{Ca}}$ & $\mathrm{I}_{\mathrm{Mg}}$ & $\mathrm{I}_{\mathrm{S}}$ & $\mathrm{I}_{\mathrm{B}}$ & $\mathrm{I}_{\mathrm{Cu}}$ & $\mathrm{I}_{\mathrm{Fe}}$ & $\mathrm{I}_{\mathrm{Mn}}$ & $\mathrm{I}_{\mathrm{Zn}}$ & $\mathrm{I}_{\mathrm{MS}}$ & NBI \\
\hline Jack Bean & -0.6 & -0.8 & -1.1 & 0.7 & 1.7 & 0.9 & 0.8 & -0.5 & 0.4 & -0.3 & -1.1 & 0.6 & $9,5 \mathrm{~A}$ \\
\hline Pigeon Pea & -0.9 & -0.5 & -1.2 & 0.7 & 1.9 & 0.9 & 0.7 & -0.3 & 0.6 & -0.2 & -1.1 & 0.7 & $9,7 \mathrm{~A}$ \\
\hline Lablab & -0.7 & -0.5 & -0.8 & 0.5 & 1.6 & 0.9 & 0.9 & -0.4 & 0.6 & -0.3 & -1.6 & 0.5 & $9,3 \mathrm{~A}$ \\
\hline $\begin{array}{l}\text { Brachiaria } \\
\text { DMS }\end{array}$ & -0.8 & -0.5 & -1.6 & 0.7 & 1.9 & 0.8 & 1.0 & -0.5 & 0.4 & -0.3 & -1.7 & 0.5 & $\begin{array}{l}10,7 \mathrm{~B} \\
0.82\end{array}$ \\
\hline CV (\%) & & & & & & & & & & & & & 17.41 \\
\hline
\end{tabular}

$\mathrm{NBI}=$ Nutritional Balance Index .

Means followed by the same letter in the column are not statistically different according to Tukey's test at 5\% significance.

Ciência Rural, v.44, n.4, abr, 2014. 
Table 4 - Macro and micronutrient mean levels of four different treatments over two experimental years. FCA/UNESP/Botucatu. 2005 and 2006.

\begin{tabular}{|c|c|c|c|c|c|c|c|c|c|c|c|}
\hline & $\mathrm{N}$ & $\mathrm{P}$ & $\mathrm{K}$ & $\mathrm{Ca}$ & $\mathrm{Mg}$ & $\mathrm{S}$ & B & $\mathrm{Cu}$ & $\mathrm{Fe}$ & Mn & $\mathrm{Zn}$ \\
\hline Jack Bean & $28 \mathrm{~A}$ & $2.1 \mathrm{~A}$ & $9 \mathrm{~A}$ & $15 \mathrm{~A}$ & $6 \mathrm{~A}$ & $3 \mathrm{~A}$ & $28 \mathrm{~A}$ & $9 \mathrm{~A}$ & 283A & $31 \mathrm{~A}$ & $31 \mathrm{~A}$ \\
\hline Pigeon Pea & $27 \mathrm{~A}$ & $2.2 \mathrm{~A}$ & $10 \mathrm{~A}$ & $13 \mathrm{~A}$ & $6 \mathrm{~A}$ & $3 \mathrm{~A}$ & $29 \mathrm{~A}$ & $11 \mathrm{~A}$ & $314 \mathrm{~A}$ & $30 \mathrm{~A}$ & $32 \mathrm{~A}$ \\
\hline Lablab & $25 \mathrm{~A}$ & $2.1 \mathrm{~A}$ & $9 \mathrm{~A}$ & $13 \mathrm{~A}$ & $7 \mathrm{~A}$ & $3 \mathrm{~A}$ & $35 \mathrm{~A}$ & $9 \mathrm{~A}$ & $325 A$ & $42 \mathrm{~A}$ & $38 \mathrm{~A}$ \\
\hline Brachiaria & 14B & $2 \mathrm{~A}$ & $9 \mathrm{~A}$ & $7 \mathrm{~B}$ & $8 \mathrm{~A}$ & 3A & $14 \mathrm{~B}$ & 7A & 204B & 39A & $23 B$ \\
\hline DMS & 6.22 & 0.36 & 1.94 & 5.46 & 2.97 & 0.21 & 10.72 & 3.21 & 64.52 & 13.52 & 7.74 \\
\hline CV 1 (\%) & 14.5 & 12.5 & 13.4 & 18.5 & 17.2 & 21.0 & 17.4 & 14.6 & 12.5 & 19.4 & 21.8 \\
\hline CV 2 (\%) & 15.2 & 11.5 & 10.5 & 16.3 & 12.5 & 13.6 & 10.2 & 9.5 & 10.6 & 11.6 & 18.5 \\
\hline
\end{tabular}

Means followed by the same letter in the column are not statistically different according to Tukey's test at 5\% significance.

Table 5 - Mean production $\left(\mathrm{kg}\right.$ plant ${ }^{-1}$ ) of orange trees subjected to four different treatments over two experimental years. FCA/UNESP/Botucatu. 2005 and 2006.

\begin{tabular}{|c|c|c|c|c|c|}
\hline Year & Jack Bean & Pigeon Pea & Lablab & Brachiaria & DMS treat. \\
\hline 2005 & $91.8 \mathrm{Aa}$ & $125.9 \mathrm{Ba}$ & 94.6Aa & 93.7Aa & 12.24 \\
\hline 2006 & $103.4 \mathrm{Ab}$ & $145.2 \mathrm{Bb}$ & $115.0 \mathrm{Ab}$ & 98.5Aa & 22.51 \\
\hline DMS Year & 9.84 & 16.39 & 13.87 & 6.54 & \\
\hline CV $1(\%)=37.0$ & & CV $2(\%)=$ & & & \\
\hline
\end{tabular}

Means followed by the same letter in the same line and column are not statistically different according to Tukey's test at 5\% significance. Uppercase letters = treatments; Lowercase letters = years.

\section{REFERENCES}

BEAUFILS, E.R. Diagnosis and recommendation integrated system (DRIS); a general scheme for experimentation and calibration based on principles develop from research in plant nutrition. Soil Science Bulletin, Pochvovedenie, v.1, p.1-132, 1973. Available from: <http://www.allertonpress.com/journals/ mus.htm>. Accessed: Jan. 2008.

CRESTE, J.E.; NAKAGAWA, J. Estabelecimento do método DRIS para a cultura do limoeiro em função da análise foliar. I Cálculo das normas. Revista Brasileira de Fruticultura, Cruz das Almas, v.19, n.3, p.245-256, 1997.

CRESTE, J.E. Perspectivas do DRIS em culturas de alta produtividade. In: PRADO, R.M.; ROZANE, D. E. et al. Nutrição de plantas - diagnose foliar em grandes culturas. Jaboticabal: Santa Terezinha, 2008. p.83-105. Available from: <http://www. nutricaodeplantas.agr.br/site/downloads/unesp_jaboticabal/ Palestras_1simposio/perspectivasd>. Accessed: Feb. 2009.

DEMATTÊ, J. L.; VITTI, G. C. Alguns aspectos relacionados ao manejo de solos para os citros. In: SEMINÁRIO INTERNACIONAL DE CITROS, 2., 1992, Bebedouro, SP. Anais... Campinas: FUNDAÇÃO CARGILL, 1992. V.1, p.69-99.

EMBRAPA. Sistema brasileiro de classificação de solos. Brasília: EMBRAPA, 1999. 412p.
MALAVOLTA, E. et al. Avaliação do estado nutricional das plantas: princípios e aplicações. Piracicaba: Potafos, 1998. 319p.

MELLO, M.H. de A. et al. Hidrologia, climatologia e agrometeorologia. In: BERTOLINI, D. et al. Potencialidades agrícolas das terras do Estado de São Paulo. Campinas: CATI, 1994. p.1-69.

QUAGGIO, J.A. et al. Frutíferas. Campinas: Instituto Agronômico, 1996. 285p. (Boletim Técnico, 100).

ROSSETTI, A.G. Influência da área da parcela e do número de repetições na precisão de experimentos com arbóreas. Pesquisa Agropecuária Brasileira, Brasília, DF, v.37, n.4, p.433-438, 2002.

SAN MARTIN MATHEIS, H.A. Uso contínuo de coberturas vegetais em citros: influência no banco de sementes, na comunidade infestante e nas características químicas do solo. 2008. 96f. Tese (Doutorado em Fitotecnia) - Programa de Pósgraduação em Fitotecnia, Escola Superior de Agricultura Luiz de Queiroz, Universidade de São Paulo, SP. Available from: < http:// www.google.com.br/search?hl=pt-BR\&source=hp\&q=Héctor+A lonso+San+Martin+Matheis\&meta=\&>. Accessed: Nov. 2008.

SILVA, J.A.A. da et al. Reciclagem e incorporação de nutrientes ao solo pelo cultivo intercalar de adubos verdes em pomar de laranjeira 'Pêra'. Revista Brasileira de Fruticultura, Jaboticabal SP, v.24, 
n.1, p.225-230, 2002. Available from: <http://www.scielo.br/ scielo.php?script=sci_arttext\&pid=S010029452002000100048\&l ng=pt\&nrm=iso\&tlng doi: 10.1590/S0100-29452002000100048>. Accessed: Dec. 2008.

VITTI, G.C. et al. Técnicas de utilização de calcário e gesso na cultura dos citros. In: SEMINÁRIO INTERNACIONAL DE CITROS - NUTRIÇÃO E ADUBAÇÃO, 4., 1996, Bebedouro, SP. Anais... Campinas: FUNDAÇÃO CARGILL, 1996. p.131-160.

VON OSTERROHT, M. O que é uma adubação verde: princípios e ações. Agroecologia Hoje, Botucatu, n.14, p.9-11, 2002. Available from: <http://www.taps.org.br/Paginas/AgroecologiaPub.html>. Accessed: Dec. 2008.

WEBER, O. B.; PASSOS, O. S. Adubação verde: aspectos relacionados a citricultura. Revista Brasileira de Fruticultura, Cruz das Almas, v. 13, n. 4, p. 295-303, out. 1991.

ZHOU, W.J. et al. Plant phosphorus uptake in a soybean-citrus intercropping system in the red soil Hilly region of South China. Pedosphere, Nanjing, v.19, n.2, p.244-250, 2009. Available from: $<2945200200001000048 \& 1 \mathrm{ng}=$ t\&\&rm=iso\&tlngdoi:10.1590/ S0100-2945200200200001000048>. Accessed: Dec. 2008. 